\title{
Application of a composite ultrafiltration membrane for biodiesel purification
}

\author{
Natalia Evelin Rodriguez ${ }^{1}$, Juan José Torres ${ }^{1}$, Nelio Ariel Ochoa ${ }^{2}$, \\ José Marchese $^{2}$, Cecilia Pagliero ${ }^{1}$
}

\author{
${ }^{1}$ Departamento de Tecnología Química - Facultad de Ingeniería - Universidad Nacional de Río Cuarto. CP: X5804BYA, \\ Río Cuarto, Córdova, Argentina. \\ e-mail: nrodriguez.rne@gmail.com \\ ${ }^{2}$ INFAP-CONICET-FONCYT - Universidad Nacional de San Luis. CP: D5700BWS, San Luis, San Luis, Argentina. \\ e-mail: jtorres@ing.unrc.edu.ar; arielochoasl@gmail.com; marchese@unsl.edu.ar; cpagliero@ing.unrc.edu.ar
}

\begin{abstract}
This study was carried out to investigate the potentialities of the application of membrane technology in biodiesel purification without need of the decantation step. A new composite UF membrane was prepared from poly(vinylidene fluoride) casting solution (17 wt $\%$ ) containing a sulfonated Carbon (20 wt $\%$ ). The assays were performed in a dead-end filtration cell with synthetic mixtures of the transesterification reaction products. The influence of two operational variables was analyzed, transmembrane pressure $(\Delta \mathrm{P}=4-8$ bar $)$ and temperature $\left(\mathrm{T}=50-60^{\circ} \mathrm{C}\right)$. The membrane performance was evaluated determining the flux and the permeate compositions. Temperature resulted to be the most important operational variable. An increase in $10^{\circ} \mathrm{C}$ duplicated the permeate flux at 6 and 8 bar. The best performance was obtained at $60^{\circ} \mathrm{C}$ and 8 bar, with a flux of $12.6 \mathrm{Lm}^{-2} \mathrm{~h}^{-1}$. In this operative conditions, the influence of the added acidified water $\left(\mathrm{W}_{\text {add }}=0-20\right.$ $\% \mathrm{v} / \mathrm{v})$ in the synthetic mixture was evaluated, which increased considerably permeate fluxes. Finally, the impact of synthetic mixture composition was determined for the assayed best operational conditions. The higher flux value was measured in the mixture with less glycerol and without soaps. In all assays the biodiesel retention was complete and the permeates were composed mainly of glycerol and ethanol.
\end{abstract}

Keywords: membranes, ultrafiltration, biodiesel, glycerol.

\section{INTRODUCTION}

The transesterification reaction between a vegetable oil and a short chain alcohol is catalyzed by a strong base such as sodium methylate or sodium hydroxide. This is the most frequent process used around the globe to obtain biodiesel (BD) [1]. However, other by-products are obtained such as glycerol (GLY), soaps (S), rest of triglycerides (TG), monoglycerides (MG), diglycerides (DG), catalyst, water and solvent [2]. Alcohol frequently used is methanol $(\mathrm{MeOH})$ because it promotes an efficient separation of the reaction by-products and high final conversions of fatty acids methyl esters (FAME). Ethanol (EtOH) is an interesting alternative to methanol as its use intensifies sustainability in the production of BD. Compared to the methanolysis, ethanolysis produces fatty acids ethyl esters (FAEE) and the obtained solutions have a larger miscibility region of the reaction products [3]. Even low water amounts in $\mathrm{EtOH}$ produces highly stable emulsions due to more content of soaps formed during the reaction [4]. Membrane technology can be used to ensure an efficient and sustainable way to purify BD made from ethanol. The downstream after the transesterification reaction can be filtrated with an adequate membrane in order to avoid the enormous water consumption needed to purify crude BD.

There are few studies on the use of membranes to purify BD. It has been reported the use of ceramic membranes of micro (MF) and ultrafiltration (UF), in the same study [5], and of nanofiltration (NF) [6]. Some researchers have worked directly with the reaction products [7, 8, 9] and others have studied synthetic mixtures prepared simulating real and likely compositions [10].

The aim of this work is to study the purification capability of different synthetic mixtures of crude BD using an UF composite membrane. The casting solution was prepared by dissolving poly(vinyliden flouride) (PVDF) (17 wt \%) in N, N-Dimethylformamide (DMF) and then sulfonated carbon (20 wt \%) was added to the polymer solution making a suspension. The mixtures were prepared from clean FAME and FAEE, soap, EtOH, GLY, and triglycerides. The mixtures simulate the products of the real biodiesel reaction found in the 
literature $[10,3,11]$.

\section{MATERIALS AND METHODS}

\subsection{Preparation of synthetic biodiesel mixtures}

Four synthetic mixtures with different compositions of FAME or FAEE, glycerol, anhydrous ethanol, semirefined soybean oil, and sodium oleate were prepared for the permeation assays. The FAME was provided by Advanced Organic Material S.A., Pilar, Argentina. The glycerol (99.5\%) and anhydrous ethanol (99.5\%) were purchased to Ciccarelli (Argentina). The semi-refined soybean oil was kindly provided by Oleaginosa General Cabrera SAIC (Argentina). The sodium oleate was purchased from Sigma-Aldrich. The FAEE was obtained in the laboratory by means of an alkaline transesterification reaction between semi-refined soybean oil and anhydrous ethanol according to data published by TORRES et al. [11], see scheme 1 . The amount of FAEE, glycerol, ethanol and soaps was determined in the reaction product.

Scheme 1: FAEE synthesis steps.

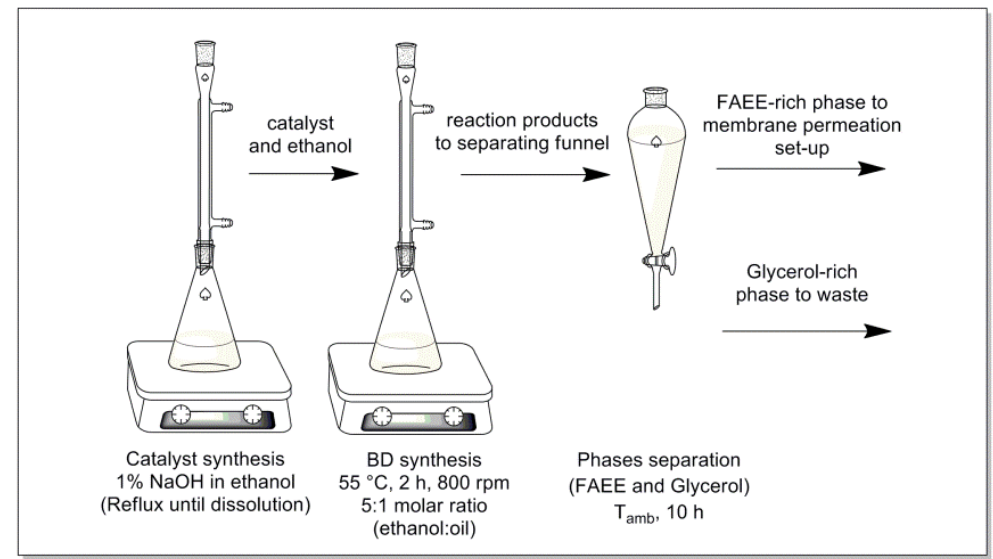

The four synthetic mixtures are summarized in Table 1. The first synthetic mixture (B1) was prepared according to data published by MENDOW et al. [3] and it was prepared from FAME, EtOH, TG (semi refined soybean oil), GLY and S (sodium oleate). In order to study if the use of FAME or FAEE has any effect on the permeation assays, a second synthetic mixture (B2) was prepared with the same composition that the first, but using the FAEE obtained in the laboratory instead of commercial FAME. The third synthetic mixture (B3) was made according to data published by GOMES et al. [10] containing only FAME, EtOH and GLY, and no S. The fourth synthetic mixture (B4) was prepared with the mass composition of the reaction product determined in our laboratory for the reaction according to TORRES et al. [11]. The products used in the manufacture of B4 were FAEE, GLY, EtOH and a high content of S.

Table 1: Synthetic mixtures used in permeation assays.

\begin{tabular}{l|l|l|l|l}
\hline Wt\% & B1 & B2 & B3 & B4 \\
\hline FAEE & - & 70.1 & - & 48.5 \\
\hline FAME & 70.1 & - & 80 & - \\
\hline GLY & 19.2 & 19.2 & 10 & 30.8 \\
\hline EtOH & 8.6 & 8.6 & 10 & 13.5 \\
\hline TG & 1 & 1 & - & - \\
\hline Soap & 1.1 & 1.1 & - & 7.2 \\
\hline
\end{tabular}




\subsection{Membrane}

\subsubsection{Materials}

The membrane PVDF17-C20 was made of poly(vinylidene fluoride) (PVDF), MW: 570-600 kDa and sulfonated carbon obtained according to TAMBORINI et al. [11]. An UF membrane was synthesized following the phase inversion process [13]. The casting solution was prepared by dissolving PVDF (17 wt $\%$ ) in $\mathrm{N}, \mathrm{N}$-Dimethylformamide (DMF) and then the sulfonated carbon $20 \mathrm{wt} \%$ was added to the polymer solution making a suspension. The procedure of preparation of the membrane was followed as in TORRES et al. [11]. Finally, this membrane was stored in distilled water.

\subsubsection{Characterization}

The morphology of the membranes was analyzed using a JMS-35 JEOL scanning electron microscope (SEM). In order to observe the membrane cross section, the samples were fractured in liquid nitrogen and coated with gold. The distribution of pore size was determined by liquid-liquid displacement (LLDP) FIRMAN et al. [14]. FT-IR analysis of the membrane was carried out to characterize the functional groups in the membrane before and after exposure to EtOH and FAEE.

\subsection{Ultrafiltration assays}

All permeation trials were conducted in a dead-end filtration set-up (scheme 2). The stainless steel $316 \mathrm{~L}$ test cell (Sterlitech HP4750, USA) has an inside diameter of $5.1 \mathrm{~cm}$, a height of $19.9 \mathrm{~cm}$, and a maximum volume capacity of $300 \mathrm{~mL}$. The membrane was supported on a sintered porous stainless-steel disc. Membrane diameter was $4.9 \mathrm{~cm}$ with an effective area $\mathrm{A}=14.6 \times 10^{-4} \mathrm{~m}^{2}$. The feed synthetic mixture was magnetically mixed with a stirred bar (coated with teflon). The transmembrane pressure $(\Delta \mathrm{P})$ was supplied by a nitrogen cylinder connected to the top of the cell and the temperature was kept constant by the temperature control of the heater plate whit magnetic stirred. The permeate was collected through a port beneath the membrane support. The permeate flux $\mathrm{J}\left(\mathrm{L} \mathrm{m}^{-2} \mathrm{~h}^{-1}\right)$ was determined by measuring the volume of permeate collected (V) during the operation time $(\mathrm{t})$ and calculated according to Equation 1 [15].

$$
J=\frac{1}{A} \frac{V}{t}
$$


Scheme 2: dead-end filtration set-up.

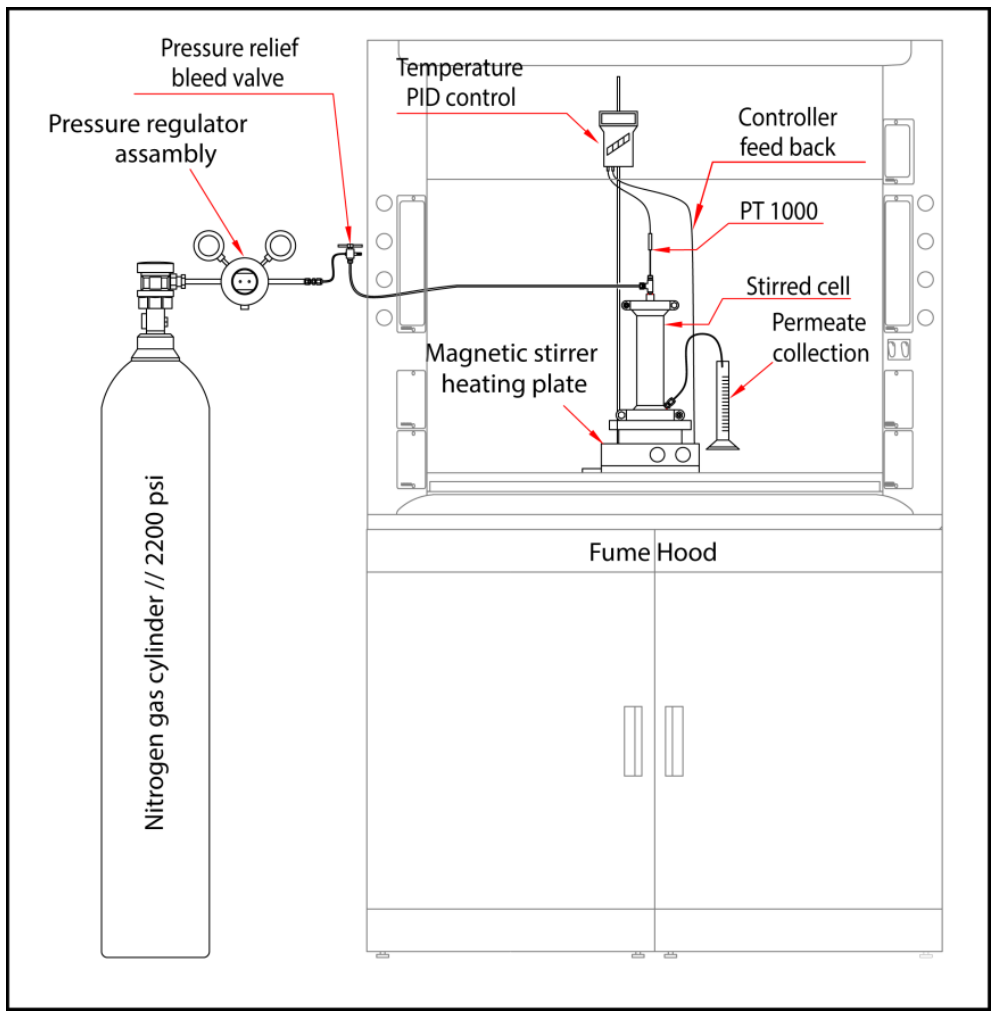

\subsubsection{Ethanol permeability}

Anhydrous ethanol was used for the hydraulic permeability determination and cleaning of the membrane. The membrane was placed in the test cell and was preconditioned by loading the reservoir with pure EtOH during 24 hours. Then the EtOH permeate flux, $\mathrm{J}_{\mathrm{EtOH}}$, was measured as a function of transmembrane pressure $\left(\Delta \mathrm{P}=2-8\right.$ bar) at two constant temperatures $\left(\mathrm{T}=50\right.$ and $\left.60{ }^{\circ} \mathrm{C}\right)$. The permeate flux values were used to evaluate $\mathrm{EtOH}$ hydraulic permeability $\left(\mathrm{L}_{\mathrm{h}, \mathrm{EtOH}}\right)$ according to Equation 2. Each experiment was carried out in triplicate.

$$
L_{h, E t O H}=\frac{J}{\Delta P}
$$

\subsubsection{Synthetic mixture permeation}

Once the pure solvent measurements were performed, the permeation assays of synthetic mixtures were carried out with and without added distilled water containing $0.5 \% \mathrm{v} / \mathrm{v}$ hydrochloric acid acidified $\left(\mathrm{W}_{\text {add }}\right)$. The amount of $\mathrm{W}_{\text {add }}$ was $0-20 \% \mathrm{v} / \mathrm{v}$. The reservoir of the cell was charged with $250 \mathrm{~mL}$ of synthetic mixture and stirred at $500 \mathrm{rpm}$. The transmembrane pressure and temperature were varied from $2-8$ bar and 50 $60^{\circ} \mathrm{C}$, respectively. The duration of the permeation assays was $120 \mathrm{~min}$ in order the reach a stationary state. All permeation trials were performed in triplicate. The permeate flux was evaluated from Equation 1 and the percentage of rejection the ' $\mathrm{i}$ ' solute $\left(\% \mathrm{R}_{\mathrm{i}}\right)$ was calculated according to the Equation 3.

$$
\% R_{i}=\left(1-\frac{C_{i, p}}{C_{i, f}}\right) 100
$$

Where $\mathrm{C}_{\mathrm{i}, \mathrm{p}}$ and $\mathrm{C}_{\mathrm{i}, \mathrm{f}}$ are the permeate and feeding concentration of ' $\mathrm{i}$ ' solute, respectively.

\subsection{Analytical determinations}

The glycerol content was determined by the official AOCS method for the analysis of free glycerol in oils 
and fats (Ca 14-56). For this technique perclhoric acid, sodium thiosulphate, potassium iodide, glacial acetic acid $(99.5 \%)$, sodium hypochlorite, chloroform, potassium dichromate, hydrochloric acid, potassium hydroxide in pellets and ethanol 95\% were purchased from Ciccarelli (Argentina). For the soap determination for AOCS Cc 17-95 titrimetric method hydrochloric acid, sodium hydroxide and biphthalate were purchased from Sigma Aldrich (Argentina). The technique was carried out with an automatic titrator plus Metrhom Titrino ${ }^{\circledR}$, equipped with a Metrohm Solvotrode electrode for non-aqueous determinations. For the humidity determination (Karl Fischer) HYDRANAL-Composite $5^{\circledR}$ reagent and anhydrous methanol as solvent were purchased from Sigma Aldrich (Argentina) and Ciccarelli (Argentina) respectively.

\section{RESULTS AND DISCUSSION}

\subsection{Characterization of membrane}

Figs. 1 (a) and (b) show SEM micrographs of the surface and cross section of the PVDF17-C20 membrane respectively.

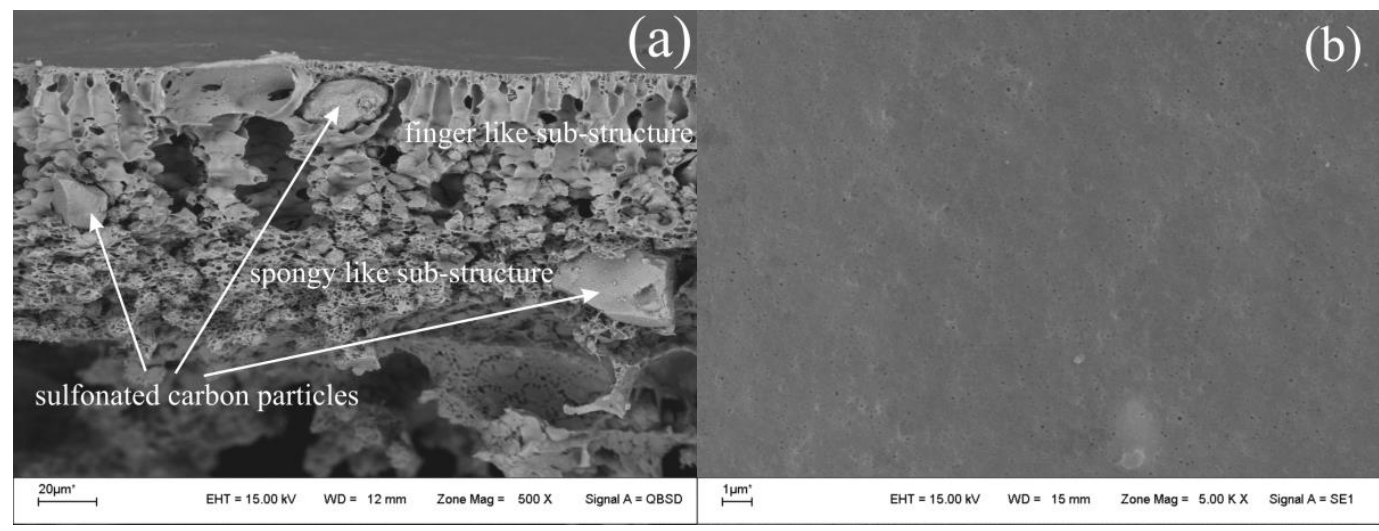

Figure 1: (a) Cross section SEM micrograph and (b) surface SEM micrograph of the membrane.

Figure 1 (a) shows two well-defined regions, a thin dense layer (selective) on the top consisting of packed nodule aggregates of polymer and underneath a thicker porous finger macrovoids. Between the finger like and spongy like structures it can be observed the presence of sulfonated carbon particles. In Figure 1 (b) it can be appreciated a smooth surface texture.

Figures 2 (a) and (b) show the distribution of pore size of the neat and used membrane, respectively. The analysis of these figures indicates a change in the average pore size of the used membrane with respect to the neat membrane $\left(r_{p}=17.8 \mathrm{~nm}\right.$ to $\left.r_{p}=10 \mathrm{~nm}\right)$. The presence of biodiesel (long-chain ethyl ester) produces a swelling that modifies the membrane polymer structure [16].
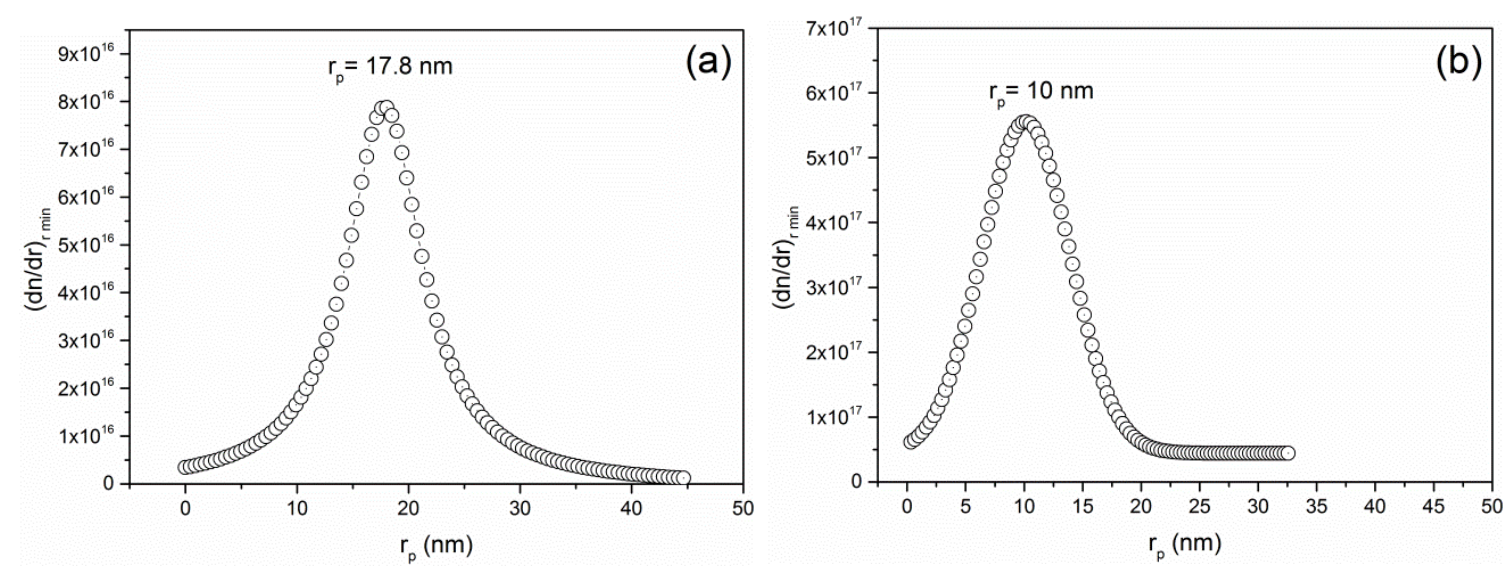

Figure 2: Distribution of pore size of the membrane, (a) neat (b) used.

Figure 3 shows a linear regression of flow data for EtOH versus trans-membrane pressure. The $\mathrm{L}_{\mathrm{h}, \mathrm{EtOH}}$ 
was obtained through slope of the fit. The satisfactory data fit $\left(\mathrm{R}^{2}=0.998\right)$ indicates that the EtOHmembrane system have a behavior that follows the Hagen-Poiseuille equation with a value of $\mathrm{L}_{\mathrm{h}, \mathrm{EtOH}}=44.9 \pm$ $1.9 \mathrm{~L} \mathrm{~m}^{-2} \mathrm{~h}^{-1}$ bar.

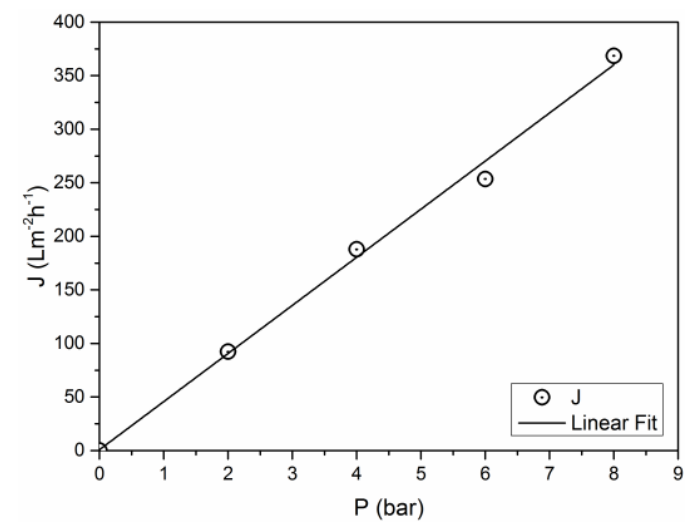

Figure 3: Ethanol hydraulic permeability.

Figure 4 shows three FTIR spectra corresponding to three membrane samples: one neat, another immersed in EtOH and another in FAEE. When the neat membrane is compared with EtOH treated membrane no changes in the spectrums were observed. However, FAEE immersed membrane shows an appreciable difference respect to neat and $\mathrm{EtOH}$ treated membranes. In this spectrum appears the following bands corresponding to FAEE, MG and DG: $\mathrm{C}=\mathrm{O}\left(1737 \mathrm{~cm}^{-1}\right), \mathrm{OH}-\left(3340 \mathrm{~cm}^{-1}\right),-\mathrm{CH}\left(3035 \mathrm{~cm}^{-1}\right)$ and $-\mathrm{CH}_{2}$ $\left(2780 \mathrm{~cm}^{-1}\right)$. These bands disappear upon successive EtOH washing. This confirms the chemical resistance of the membrane to the study mixture.

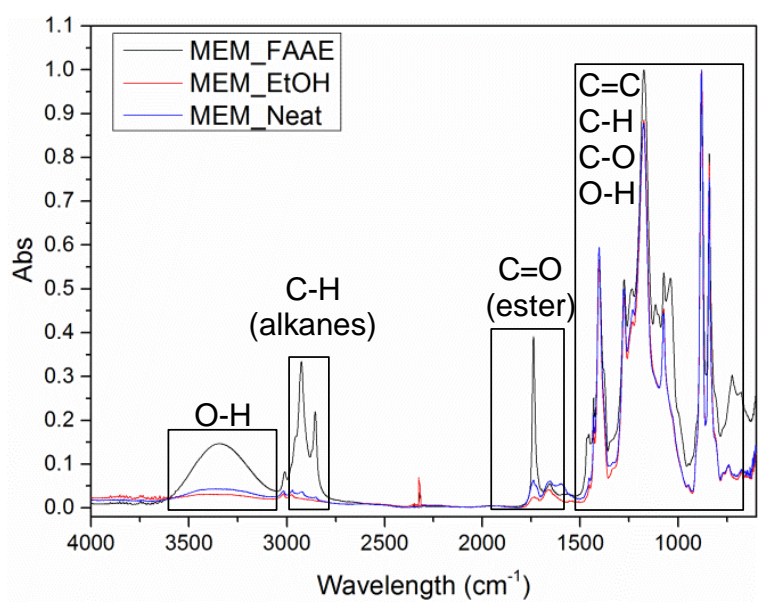

Figure 4: FT-IR of PVDF17- C20 membrane.

\subsection{Permeability of synthetic mixtures}

All permeation trials were carried out in triplicate. Mean values were used to plot the curves and calculate standard deviations. A good reproducibility in the permeation data was observed, within 5\% deviation. The average permeate flux values between $\mathrm{t}=100 \mathrm{~min}$ and $\mathrm{t}=120 \mathrm{~min}, \mathrm{~J}^{*}$, were used as reference fluxes to evaluate the membrane permselective performance.

\subsubsection{Influence of the transmembrane pressure and the temperature on permeate flux}

The experiments shows that the temperature is the most relevant variable on permeate flux. This effect is due to a well known diminution of the viscosity value as temperature increase. For example, for B1 an increase in $10^{\circ} \mathrm{C}$ increase the permeate flux from 6.3 to $11.7 \mathrm{~L} \mathrm{~m}^{-2} \mathrm{~h}^{-1}$ at 6 bar and from 6.1 to $15.1 \mathrm{~L} \mathrm{~m}^{-2} \mathrm{~h}^{-1}$ at 8 bar.

Figure 5 is the representation of the permeate flux vs time performed at $60{ }^{\circ} \mathrm{C}$ and different transmembrane pressures $(4,6$ and 8 bar). In the three experiments, a reduction in the initial flow can be 
observed until reaching a constant flow value for $\mathrm{t}>100 \mathrm{~min}$. When the flow data expressed as $\mathrm{J}^{*}$, are measured vs pressure for the three experiments (Figure 6), it can be concluded that the system complies to the Hagen-Pouseille equation. However, when the measured data are plotted at $50{ }^{\circ} \mathrm{C}$ a significant deviation to the linear regression is verified in Figure 6 . At $\mathrm{T}=60^{\circ} \mathrm{C}$, the permeate flux is proportional to the applied pressure and therefore the filtration is controlled by pressure while at $50{ }^{\circ} \mathrm{C}$ the permeate flow approaches a limit value independent of pressure increments indicating a mass transfer controlled region.

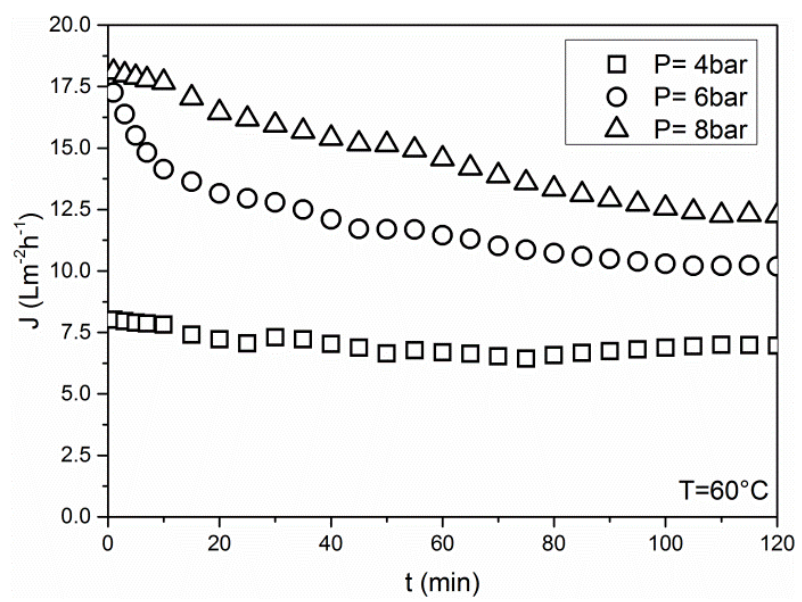

Figure 5: Permeate flux as a function of the filtration time for B1 at $4 ; 6$ and 8 bar and $\mathrm{T}=60^{\circ} \mathrm{C}$.

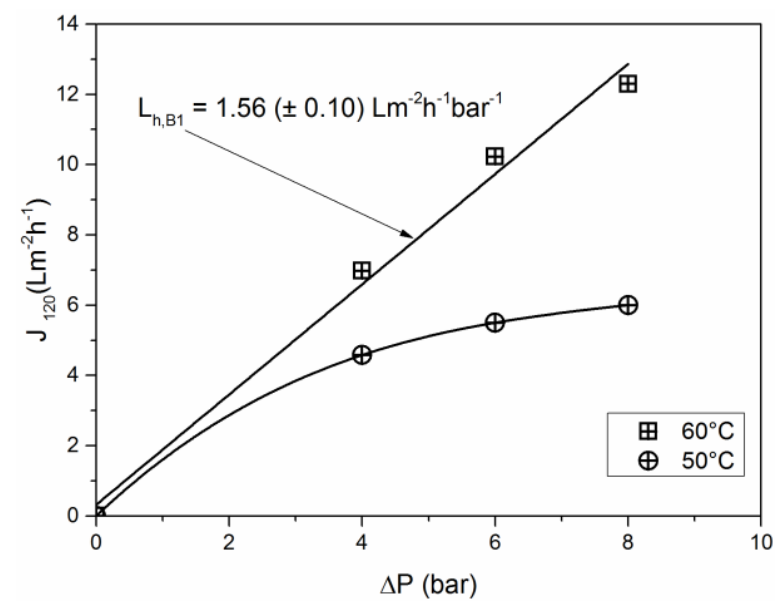

Figure 6: Effect of $\Delta \mathrm{P}$ on steady-state permeate flux for $\mathrm{B} 1\left(\mathrm{~T}=50\right.$ and $\left.60^{\circ} \mathrm{C}\right)$. 


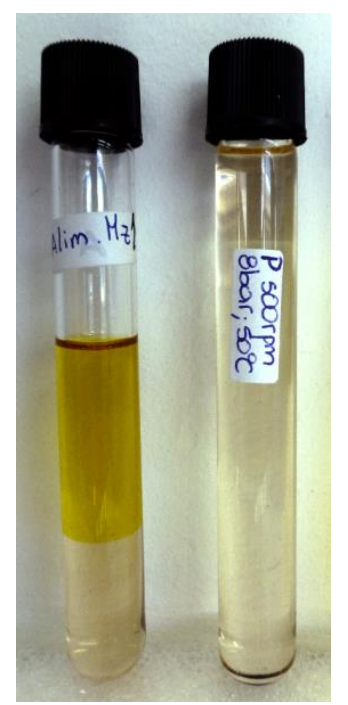

Figure 7: Feed (a) and permeate (b) samples. 8 bar, $50{ }^{\circ} \mathrm{C}$.

In Figure 7, feed and permeates are shown. Permeated obtained from all experiments show predominantly the presence of GLY and EtOH without the ester phase (Figure 7). In Table 3, a negative retention for soaps and water present in the B1 synthetic mixture is observed. The same phenomenon is observed in B2 and B4. Soaps and water are concentrated in the permeate. Soaps retention decreases with the temperature whereas no significant trend is observed for water retention.

Table 3: $\mathrm{S}$ and $\mathrm{W}$ retention for assays whit $\mathrm{B} 1$.

\begin{tabular}{l|l|l|l|l|l}
\hline & & \multicolumn{2}{|c|}{ SOAP } & \multicolumn{2}{c}{ WATER $^{\ddagger}$} \\
\hline $\mathbf{T}\left({ }^{\circ} \mathbf{C}\right)$ & $\mathbf{P}$ (bar) & $\mathbf{C}_{\mathbf{P}}$ & \%R & $\mathbf{C}_{\mathbf{P}}$ & \%R \\
\hline \multirow{3}{*}{50} & 4 & 1.5 & -36 & 1.4 & $-75 \%$ \\
\cline { 2 - 7 } & 6 & 1.7 & -55 & 1.5 & $-88 \%$ \\
\cline { 2 - 7 } & 8 & 1.6 & -45 & 1.3 & $-63 \%$ \\
\hline \multirow{3}{*}{60} & 4 & 1.8 & -64 & 0.9 & $-13 \%$ \\
\cline { 2 - 7 } & 6 & 1.9 & -73 & 1.9 & $-88 \%$ \\
\cline { 2 - 7 } & 8 & 1.8 & -64 & 0.9 & $-13 \%$ \\
\hline
\end{tabular}

${ }^{\dagger}$ feed concentration $1.1 \mathrm{wt} \% .{ }^{*}$ feed concentration $1.05 \mathrm{wt} \%$.

\subsubsection{Influence of the concentration of acidified water on permeate flux}

The presence of added water $\left(\mathrm{W}_{\text {add }}\right)$ increase considerably the permeate fluxes (Figure 8). Only with $5 \% \mathrm{v} / \mathrm{v}$ of $\mathrm{W}_{\text {add }}$ the flux increases four times, with $10 \% \mathrm{v} / \mathrm{v}$ six times and with $20 \% \mathrm{v} / \mathrm{v}$ twenty times. The Table 4 shows that the increase of permeate flux with $\mathrm{W}_{\text {add }}$ is very noticeable. This increase of $\mathrm{J}$ can be attributed to a decrease in the viscosity value in the mixture as water content increases. 


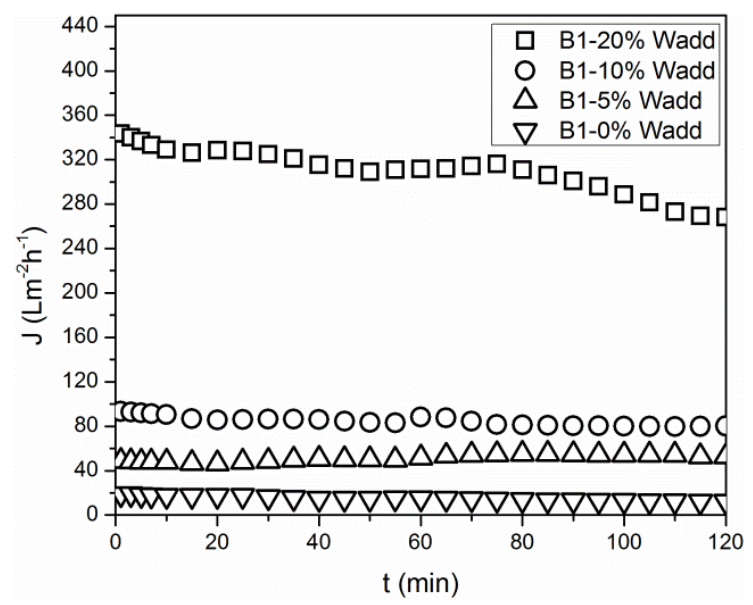

Figure 8: Permeate flux as a function of the filtration time for $\mathrm{B} 1 . \mathrm{T}=60^{\circ} \mathrm{C}, \mathrm{P}=8$ bar.

Table 4: Values of $\mathrm{J}^{*}$ for $\mathrm{B} 1$ with different amount of $\mathrm{W}_{\text {add }} \mathrm{T}=60^{\circ} \mathrm{C}, \mathrm{P}=8$ bar.

\begin{tabular}{l|l}
\hline$\% \mathbf{W}_{\text {add }}$ & $\mathbf{J}^{\star}$ \\
\hline 0 & 12.6 \\
\hline 5 & 53.7 \\
\hline 10 & 79.9 \\
\hline 20 & 267.2 \\
\hline
\end{tabular}

Permeates obtained in experiments with $\mathrm{W}_{\text {add }}$ shows the presence of GLY, EtOH, $\mathrm{S}$ and W, without the ester phase. The membrane has a negative retention respect to $S$. This produce a concentration of $S$ in permeates, equal as in the assays without $\mathrm{W}_{\text {add }}$.

\subsubsection{Influence of the composition of the mixtures}

In order to evaluate the effect of the composition of the synthetic mixtures, a further set of permeation experiments were performed using all of the mixtures B1, B2, B3 and B4 at the same operating conditions (T $=60{ }^{\circ} \mathrm{C}$ and $\mathrm{P}=8$ bar). The permeates of all samples contain GLY and EtOH. The observed fluxes values for B1 and B2 after 25 minutes of permeation shown no appreciable differences. This indicates that the use of FAME or FAEE in the preparation of synthetic mixtures has a negligible effect.

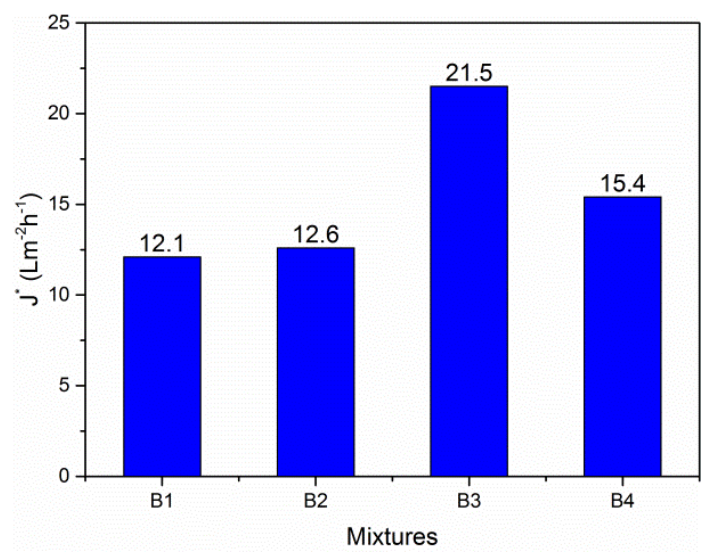

Figure 9: Steady-state permeate flux all mixtures at $\mathrm{T}=60^{\circ} \mathrm{C}$ and $\Delta \mathrm{P}=8 \mathrm{bar}$

The highest flux value for B3 (Figure 9) can be addressed to the lack of soaps whereas the determined flux for B4 can be related to the high content of GLY and EtOH. 


\section{CONCLUSIONS}

A mixed matrix UF membrane was prepared from PVDF and sulfonated carbon for biodiesel purification. It was found that temperature is an important variable in $\mathrm{BD}$ filtration. An increase in $10{ }^{\circ} \mathrm{C}$ duplicates the permeate flux at the two transmembrane pressure tested ( 6 and 8 bar). The best performance obtained of flux value was $12.6 \mathrm{Lm}^{-2} \mathrm{~h}^{-1}$ at $60{ }^{\circ} \mathrm{C}$ y 8 bar. In all cases, the permeation of soaps and water showed negative rejections. Analyzing the composition of the mixtures, the highest flux was observed in the mixture prepared without soaps. The results obtained in experiments with added water to the synthetic mixtures indicate a substantial improvement in the permeate fluxes as water content is increased. In all assays the biodiesel retention was complete and permeates was composed of glycerol, ethanol, soaps and water. These results indicate that this membrane can be used as an attractive alternative process for the BD purification.

\section{ACKNOWLEDGMENTS}

The authors thank the National Council for Scientific and Technical Research (CONICET), UNRC, UNSL and ANPCYT for the support provided in this work.

\section{BIBLIOGRAPHY}

[1] YUSUF, N. N. A. N., KAMARUDIN, S. K., YAAKUB, Z. "Overview on the current trends in biodiesel production", Energy Conversion and Management, v. 52, pp. 2741-2751, Mar. 2011.

[2] MA, F, HANNA, M. A., "Biodiesel production: a review", Bioresour Technology, v. 70, n. 1, pp. 1-15, Oct. 1999.

[3] MENDOW, G., VEIZAGA, N.S., QUERINI, C.A., "Ethyl ester production by homogeneous alkaline transesterification: influence of the catalyst", Bioresour Technology, v. 102, n. 1, pp. 6385-6391, Jan. 2011.

[4] EZE, V. C., HARVEY, A. P., PHAN, A. N., "Determination of the kinetics of biodiesel saponification in alcoholic hydroxide solutions", Fuel, v. 140, pp 724-730, Jan 2015.

[5] CHENG, L., CHENG, Y., YEN, S., CHEN, J., "Ultrafiltration of triglyceride from biodiesel using the phase diagram of oil-FAME-MeOH”, Journal of Membrane Science, v.330, n. 1, pp. 156-165, Jan. 2009.

[6] OTHMAN, R., MOHAMMADA, A. W., ISMAIL M., et al., "Application of polymeric solvent resistant nanofiltration membranes for biodiesel production", Journal of Membrane Science, v.348, n. 1, pp. 287-297, Nov. 2010.

[7] GOMES, M. C. S., ARROYO, P. A., PEREIRA, N. C., "Biodiesel production from degummed soybean oil and glycerol removal using ceramic membrane", Journal of Membrane Science, v. 378, pp. 453-461, May. 2011.

[8] GOMES, M. C. S., ARROYO, P. A., PEREIRA, N. C., "Influence of acidified wáter on the biodiesel and glicerol separation through membrane technology", Journal of Membrane Science, v. 431, pp. 28-36, Jan. 2013.

[9] GOMES, M. C. S., ARROYO, P. A., PEREIRA, N. C., "Influence of oil quality on biodiesel purification by ultrafiltration", Journal of Membrane Science, v. 496, pp. 242-249, Sep. 2015.

[10] GOMES, M. C. S., PEREIRA, N. C., BARROS, S. T. D., "Separation of biodiesel and glycerol using ceramic membranes", Journal of Membrane Science, v. 352, pp. 271-276, Feb. 2010.

[11] TORRES, J. J., RODRIGUEZ, N. E., TOLEDO ARANA, J., et al., "Ultrafiltration polymeric membranes for the purification of biodiesel from ethanol", Journal of Cleaner Production, v. 141, pp. 641647, Sep. 2016.

[12] TAMBORINI, L.H., MILITELLO, M.P., BALACH, J., et al., "Application of sulfonated nanoporous carbons as acid catalysts for Fischer esterification reactions", Arabian Journal of Chemistry, 2015. In press. http://dx.doi.org/10.1016/j.arabjc.2015.08.018.

[13] KESTING, R. E., Synthetic Polymeric Membranes. A Structural Perspective, first ed. WileyInterscience, New York, 1985.

[14] FIRMAN, L., OCHOA, N., MARCHESE, J., et al., "Deacidification and solvent recovery of soybean oil by nanofiltration membranes", Journal of Membrane Science, v. 431, pp. 187-196, Jan. 2013.

[15] OCHOA, N., PAGLIERO, C., MARCHESE, J., MATEA, M., "Ultrafiltration of vegetable oils: degumming by polymeric membranes", Separation and Purification Technology, v. 22-23, pp. 417-422. Mar. 2001. 
RODRIGUEZ, N.E.; TORRES, J.J.; OCHOA, N.A., et al. revista Matéria, v. 23, n. 2, 2018.

[16] VANDEZANDE, P., GEVERS, L.E.M., VANKELECOM, I.F.J., "Solvent resistant nanofiltration: separating on a molecular level", Chemical Society, v. 37, pp. 635-405. Oct. 2008. 